\title{
Study of Packaging Variations on the Quality of Instant Tomato Powder Drinks
}

\author{
Faidliyah Nilna Minah*, Siswi Astuti \\ Chemical Engineering Department \\ National Institute of Technology (ITN) \\ Malang, Indonesia \\ nilnaminah@yahoo.com
}

\begin{abstract}
Instant drinks are already a major requirement to fulfill human consumption in the era of globalization. According to the national health department, more than $5 \%$ of Indonesians consume instant drinks from various types. This figure is an opportunity for us to conduct research that produces quality drinks and maintains their nutritional content and vitamins. The research about how to produce quality instant drinks once minimizing the negative impact on instant beverage products is still very much debated. This research was conducted using the vacuum evaporator method with variations in temperature, time and filler in the evaporation process. The product that has been produced is analyzed for vitamins and antioxidant. The next stage is determine the parameters for designing a vacuum evaporator and also use various types of packaging such as polypropylene plastic and aluminum foil, so that the application of this tool can be used as a reference for home industries to produce healthy instant drinks and nutritious that is instant tomato drinks which rich in vitamins and antioxidants that can be stored for a long time without using preservatives but using appropriate packaging
\end{abstract}

Keywords- Instant Tomato Powder Drinks, Vacuum Evaporator, Antioxidants, Polypropylene Packaging, Aluminum Foil

\section{INTRODUCTION}

\section{A. Background}

Indonesia is a country with a very large population. Number of Indonesian population to world countries (science.com) With a very large population, Indonesia is one of the countries that is very attractive and stable as any commodity market. The impact of globalization on the millennium as it is now penetrates various fields. And unfortunately with a very large population today, Indonesia cannot yet become its own country market. Almost all fields and sectors are controlled by goods made from abroad. You will be rich in quality ingredients that will produce even better quality items. The level of HR capability, technology transfer and often are not in line. As a developing country where the main fields of education and development in the field of food will be a priority scale. National Research Priorities include the fields of food security \& health technology and medicine. Fruits and vegetables are one of the agricultural products that have the potential to be developed in the framework of food security. Besides that, as raw material is very easy to market because of its strategic role as a nutrient and vitamin. One of the many types of vegetables that grow in Indonesia. Tomato is one of the horticultural commodities with high economic value. As Wa
Ode wrote, Tomatoes are one of the most important in Indonesia, which has prospects in improving the standard of living of farmers [1]. The importance of tomatoes as an important factor in life as a producer and the wider community as consumers is also conveyed by Neni Heriani [2]. In tomatoes, there are many substances that are beneficial to the human body. Substances contained in it are vitamin $\mathrm{C}$ and vitamin $\mathrm{A}$ [3]. In addition, according to Pudjiatmoko that in $100 \mathrm{~g}$ of tomatoes contain protein $(1 \mathrm{~g})$, carbohydrates $(4.2 \mathrm{~g})$, fat $(0.3 \mathrm{~g})$, calcium $(5 \mathrm{mg})$, phosphorus $(27 \mathrm{mg})$, iron $(0.5 \mathrm{mg})$, vitamin A (carotene) $1500 \mathrm{SI}$, vitamin B (thiamine) $60 \mathrm{mg}$ and vitamin C $40 \mathrm{mg}$ [4]. With high nutritional content in tomatoes, tomatoes are one of the most consumed fruits or vegetables by people around the world. This consumption in addition to fresh fruit can also be used as raw materials for the industry of tomato sauce, jam, canned fruit, cooking spices, and others. Where the consumption of fresh and processed tomatoes increases with increasing population and awareness of the importance of balanced nutrition [5]. Seeing the extraordinary potential of tomatoes, the research on tomato fruit and their preparations is really worth considering. Therefore, one of the preparations carried out in this study was to study the role of packaging in maintaining the quality of instant tomato powder drinks.

\section{B. Literature review}

Tomato processed products play an important role in improving public health. According to research tomatoes which are crushed or cooked have a better source of lycopene than whole tomatoes, because during the heating process there is isomerization and oxidation. Consumption of tomatoes that are not cooked will not increase the serum concentration of lycopene. A prospective study of tomato products, lycopene and its effect on cancer risk proves that regular consumption of processed tomato or lycopene products can reduce the risk of prostate cancer [6]. One of the tomato processed products made in this study was instant tomato powder drink. Where the packaging role in maintaining the quality of this powder drink is very important. Some studies on the importance of packaging in food products include research by Reski mei Candra where the research reviews various kinds of plastic packaging that are suitable for food products and can be used by companies to determine the type of packaging to be used in handling their products [7]. The results of research from Hafriyanti stated that PP plastic packaging types have a better influence in maintaining the quality of beef compared to PE plastic [8]. The same thing was written by Dea Tio Mareta 
where PP plastic has a lower permeability than PE so it is better in maintaining the quality of food products [9]. Muhammad Nur also stated that PP plastic has better quality than platinum $P E$ as a milkfish wrapper [10]. The advantages of PP plastic compared to PE plastic are also examined by Achmad Furqon in his research entitled "The effect of packaging types and length of storage on nugget products" [11]. According to EBook Makanan.com for dry food type food products and Serelia used LDPE coated paper or aluminum foil, PET or PE or Aluminum foil / PE paper [12]. Aluminum foil has the advantage of high storability because it is not penetrating hermentis. Whereas glass is a safe packaging for food.

In addition to maintaining the quality of food products, the packaging function is a means of promoting food products and has an appeal to consumers, thus affecting consumers' perception of food products in it [13]. According to Wahyudie, the proper handling of packaging can actually increase income from food product sellers [14]. This can be seen when food packaging is developed into a vacuum packaging, it shows a significant relationship to the increase in the gross profit of business operators. In his research Syamsuddin stated that the packaging function was not only as a container [15]. But the packaging can be a marketing tool that can increase the value of sales if the producer really pays attention to the functions of the packaging. Because packaging is the last sight of a consumer who can be trusted and can determine whether consumers buy their products or not.

Seeing the importance of the packaging function in maintaining food quality and selling value of these food products, in this study various kinds of packaging were used such as PE Plastic, PP Plastic, plastic bottles, glass bottles, aluminum foil, and plastic coated aluminum foil. And which packaging is the best analyzed to maintain the quality of instant tomato powder drinks in terms of vitamin C content, antioxidant levels, brightness and red color of the product.

\section{MATERIAL AND METHODS}

This research was conducted with the experimental method and data analysis through graphs. Where this research activity was conducted at the Food Engineering Laboratory of Chemical Engineering ITN Malang. And analysis activities are also supported by other laboratories around Malang.

\section{A. Research Materials and Tools}

This study uses raw materials of fresh tomatoes which are processed into instant tomato powder drinks through a vacuum evaporator process which is then analyzed for the content of vitamins and antioxidants and given packaging that can extend the shelf life of the instant tomato powder drink.

The ingredients used include:

- Tomato

- Sucrose

- Tween 80

The tools used include:

- Reducing size
- Mixer

- Agitator

- Vacuum evaporator

- Dryer

\section{B. Research Methods}

This research was carried out in stages including:

- Preparation of raw materials

- Extraction process

- The process of making instant tomato powder drinks

- Product characterization where products are packaged using different packaging, namely plastic bottles, glass bottles, PP plastic, PE plastic, aluminum foil, plastic coated aluminum foil and analyzed for vitamin $\mathrm{C}$ content and antioxidant levels starting from 0 to 10 weeks storage time.

Where the process can be seen in the following research framework:

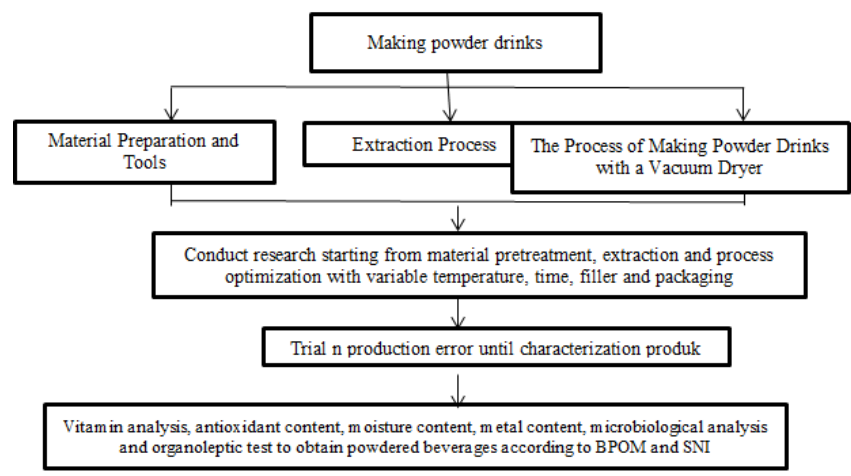

Figure1. Research scheme image Instant tomato powder drink

\section{RESULT AND DISCUSSION}

This study produced instant tomato powder beverage products which were then analyzed for vitamin $\mathrm{C}$ content and antioxidant levels which were then observed during storage times of $0,2,4,6,8$ and 10 weeks. The results of the product analysis can be seen in Figure 2 graph below. In the figure, it can be seen that the average on the second week of storage decreased the antioxidant content which then increased again in the fourth week and reached the highest value in the sixth week which then decreased again until the 10th week. $9 \%$. This is due to many factors that influence the results of product analysis, that is, in addition to the different raw materials for each production, it can also be caused by different product storage conditions for each week's storage time. But by analyzing each packaging material, the PP plastic has a better advantage than other packaging in maintaining the stability of antioxidant levels during the storage period. Plastic bottles also have these advantages with higher antioxidant levels that can be used as an alternative packaging.

Whereas for vitamin $\mathrm{C}$ content in instant tomato powder drinks can be seen in figure 3 below. On the chart as a whole, vitamin $\mathrm{C}$ levels look stable during the storage period until the eighth week and appear to increase in the 
tenth week. The use of PP plastic as a packaging also shows better stability in maintaining the vitamin $\mathrm{C}$ content in instant tomato powder drinks compared to other packaging. According to Dewi Kumalasari's research variations in packaging did not have an effect on decreasing vitamin $\mathrm{C}$ levels but the effect on vitamin $C$ was storage time [16]. However, this is not the case for research conducted by Sri Wulandari which shows that the type of packaging and length of storage time and interaction both influence vitamin $\mathrm{C}$ levels [17]. The same research results were also presented by Rani Rachmawati [18].

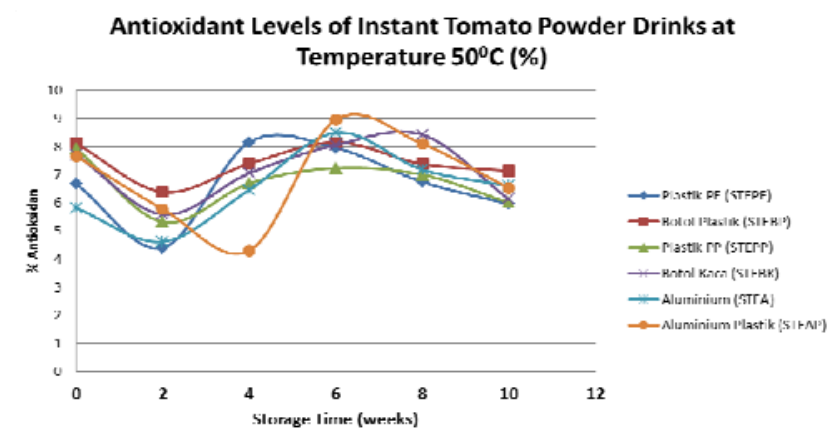

Figure2. Graph of Antioxidant Levels in Instant Tomato Powder Drinks on Various Packages

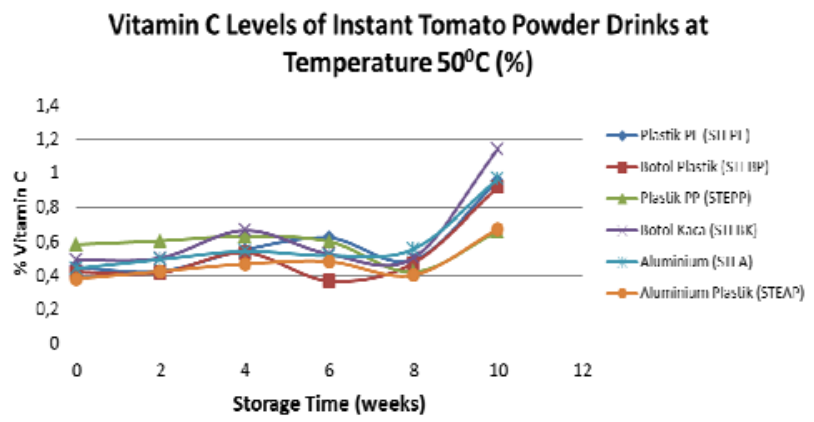

Figure 3. Graph of Vitamin C Levels in Instant Tomato Powder Drinks on Various Packages

On the analysis of brightness level test is shown in figure 4 below, where in each packaging used it looks able to maintain the brightness level of instant tomato powder beverage products until the tenth week. In numerical terms, it can be said that the plastic-coated aluminum foil packaging is better in maintaining the stability of the product brightness compared to other packaging. This is according to the nature of the packaging Aluminum foil which is not translucent and can withstand the oxidation process of the product in it so that the product is maintained in its color quality. While the level of redness or red color can be observed in figure 5 below, where from the graph it can be seen in each package that the instant tomato powder drink for the red color analysis of the product starts to appear decreasing in the sixth week until the tenth week. This shows that with the passage of storage, the quality of instant tomato powder products changes even though it is not a significant change. From the graph, it is also seen that plastic-coated aluminum packaging that is hermetic can maintain product color stability compared to other packaging.

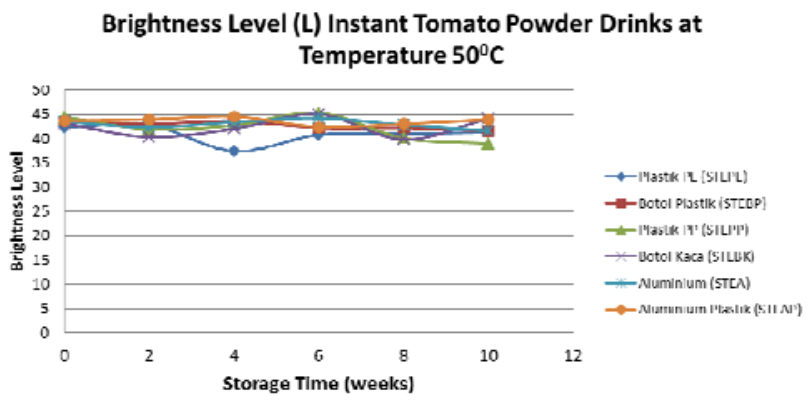

Figure 4. Graph of Brightness Levels in Instant Tomato Powder Drinks on Various Packages

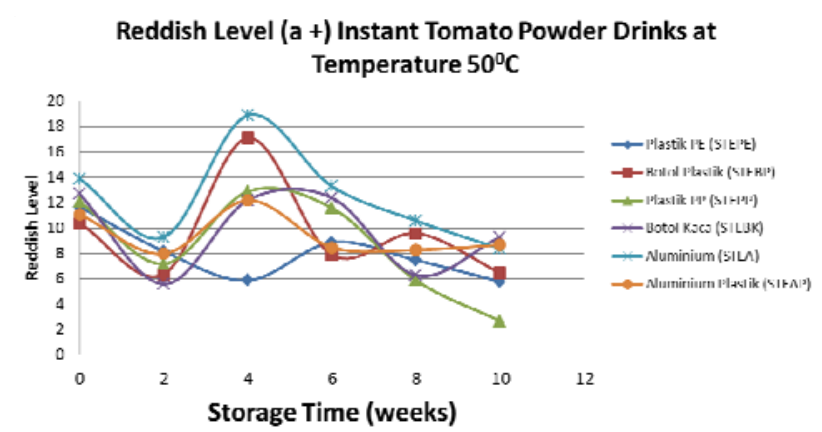

Figure 5. Reddish Level Chart on Instant Tomato Powder Drinks on Various Packages

\section{CONCLUSION}

Based on the results of data analysis it can be concluded that for all types of packaging, the average is able to maintain the quality of instant tomato powder drinks until the tenth week. In maintaining antioxidant and vitamin content by graph analysis, it was found that PP plastic packaging was better than other packaging in maintaining the stability of nutritional quality of instant tomato powder beverage products. Whereas in maintaining the quality of brightness and color of the product, the packaging of aluminum foil plastic coating shows the best results compared to other packaging.

\section{ACKNOWLEDGMENT}

Thank you to the Ministry of Research and Technology of the Higher Education as the State Institution that has funded the research we have conducted, ITN Malang as the Institution where researchers are domiciled, which provides support for facilities and infrastructure. And related laboratories around Malang. 


\section{REFERENCES}

[1] Wa Ode Sahera, Laode Sabaruddin, La Ode Safuan. "Growth and Production of Tomatoes (Lycopersicum Esculentum Mill) in Various Doses of Bokashi Cow Manure and Planting Distance ".(Pertumbuhan Dan Produksi Tomat (Lycopersicum Esculentum Mill) Pada Berbagai Dosis Bokashi Kotoran Sapi Dan Jarak Tanam). Berkala PENELITIAN AGRONOMI. 2012. Vol. 1 No. 2. 102-106 ISSN: 2089-9858

[2] N. Heriani, W. Abbas Zakaria, A. Soelaiman. "Benefit and Risk Analysis of Tomato Agriculture in Sumberejo Subdistrict, Tanggamus District". (Analisis Keuntungan Dan Risiko Usahatani Tomat Di Kecamatan Sumberejo Kabupaten Tanggamus). JIIA. 2013. Vol 1. No. 2.

[3] Syehlania Tursilawati, Damanhuri, dan Sri Lestari Purnamaningsih. "Power Test of Organic Tomatoes (Lycopersicum Esculentum Mill.) Results". (Uji Daya Hasil Tomat (Lycopersicum Esculentum Mill.) Organik). Jurnal Produksi Tanaman. 2016. Volume 4. Nomor 4. hlm. $283-290$

[4] Ainun Marliah, Mardhiah Hayati dan Indra Muliansyah. 2012. "Utilization of Liquid Organic Fertilizer on Growth and Yield of Tomato Varieties (Lycopersicum Esculentum L.)". (Pemanfaatan Pupuk Organik Cair Terhadap Pertumbuhan Dan Hasil Beberapa Varietas Tomat (Lycopersicum Esculentum L.)). Jurnal Agrista. 2012. Vol. 16. No. 3.

[5] Elis Kartika, Zulfahri Gani, dan Diki Kurniawan. "Response of Tomatoes (Lycopersicum Esculentum. Mill) Plants for Provision of Organic and Inorganic Fertilizer Combinations ". (Tanggapan Tanaman Tomat (Lycopersicum Esculentum. Mill) Terhadap Pemberian Kombinasi Pupuk Organik Dan Pupuk Anorganik). 2013. Volume 2 No. 3 Juli - September 2013. ISSN :2302-6472.

[6] Evy Damayanthi, Lilik Kustiyah, Mahani Khalid, dan Henry Fariza. "Antioxidant activity of bran is higher than Tomato juice and decreases the activity of antioxidant serum after intervention Antioxidant-rich drink". (Aktivitas Antioksidan Bekatul Lebih Tinggi Daripada Jus Tomat Dan Penurunan Aktivitas Antioksidan Serum Setelah Intervensi Minuman Kaya Antioksidan). Journal of Nutrition and Food. 2010. 5(3): 205-210

[7] Reski Mai Candra1, Dianing Sucita. "Plastic Type Determination Expert System Based on Plastic Properties of the Food to be Packed Using Certainty Factor Method (Case Study: CV. Minapack Pekanbaru)". (Sistem Pakar Penentuan Jenis Plastik Berdasarkan Sifat Plastik Terhadap Makanan yang akan Dikemas Menggunakan Metode Certainty Factor (Studi Kasus : CV. Minapack Pekanbaru)), Jurnal CoreIT. 2015 Vol.1, No.2. ISSN: 2460-738X

[8] Hafri Yanti, Hidayati Dan Elfawati. "Quality of Beef with PE (Polyethylen) Plastic Packaging and PP Plastic (Polypropylen) at Arengka Market Pekanbaru City". (Kualitas Daging Sapi Dengan Kemasan Plastik PE (Polyethylen) Dan Plastik PP (Polypropylen)
Di Pasar Arengka Kota Pekanbaru). Jurnal Petemakan. 2008.Vol 5 No 1. (22 - 27), ISSN 1829 - 8729

[9] Dea Tio Mareta, Shofia Nur A. "Packaging Vegetable Products With Plastic Box Material In Storage Of Room Temperature And Cold Temperature". (Pengemasan Produk Sayuran Dengan Bahan Kemas Plastik Pada Penyimpanan Suhu Ruang Dan Suhu Dingin). MEDIAGRO. 2011. VOL. 7. NO 1, 2011: HAL 26 - 40

[10] Muhammad Nur. "The Effect of Packaging Method, Type of Packaging Material, and Storage Time on Chemical Properties, Microbiology, and Organoleptics of Milkfish Satay (Chanos Chanos". (Pengaruh Cara Pengemasan, Jenis Bahan Pengemas, Dan Lama Penyimpanan Terhadap Sifat Kimia, Mikrobiologi, Dan Organoleptik Sate Bandeng (Chanos Chanos)). Jurnal Teknologi dan Industri Hasil Pertanian. 2009. Volume 14, No.1

[11] Achmad Furqon A. Q, Iffan Maflahah, Askur Rahman. "The Effect of Packaging Types and Storage Time on the Quality of Blowing Nugget Products". (Pengaruh Jenis Pengemas Dan Lama Penyimpanan Terhadap Mutu Produk Nugget Gembus). AGROINTEK. 2016. Volume 10, No.2

[12] Ebook Pangan. 2007. "Pengemas bahan Makanan"

[13]Dian Adi Anggraeni Elisabeth. "The Influence of Packaging and Labeling on Acceptance of Dry Noodles Made from Composite Flour of Sweet Potatoes and Keladi”. (Pengaruh Pengemasan Dan Pelabelan Pada Penerimaan Mi Kering Berbahan Baku Tepung Komposit Ubi jalar Dan Keladi). Jurnal Matematika, Saint, dan Teknologi. 2017. Volume 18, Nomor 2. 111-119

[14] Wahyudie, I.A. "Improved Packaging Performance and Marketing Strategies (Ibm Measures for Getas Crackers)". (Peningkatan Performa Kemasan Dan Strategi Pemasaran (Ibm Ukm Pengerajin Kerupuk Getas) ). Jurnal ROTOR.2016. Edisi Khusus No. 2

[15] Syamsudin, Farid Wajdi, 2015, "Desain Kemasan Makanan Kub Sukarasa Di Desa Wisata Organik Sukorejo Sragen” BENEFIT Jurnal Manajemen dan Bisnis Volume 19, Nomor 2, Desember 2015, hlm 6878.

[16]Dewi Kumalasari dan Nurhidajah. "Kub Sukarasa Food Packaging Design at Sukorejo Organic Tourism Village, Sragen”. (Variasi Jenis Kemasan Dan Lama Penyimpanan Pada Suhu Ingin Terhadap Kadar Vitamin C Dan Daya Terima Jam Rosella (Hibiscus Sabdariffa)). Jurnal Pangan dan Gizi. 2011. Vol. 02 No. 03.

[17] Sri Wulandari, Yusnida Bey dan Kartini Desyani Tindaon. "Effect of Packaging Materials and Storage Time on Vitamin C Levels and Weight Loss of Chili Rawit (Capsicum Frutescens L.)". (Pengaruh Jenis Bahan Pengemas Dan Lama Penyimpanan Terhadap Kadar Vitamin C Dan Susut Berat Cabai Rawit (Capsicum Frutescens L.)). Jurnal Biogenesis. 2012. Vol. 8, Nomor 2.

[18]Rani Rachmawati, Made Ria Defiani, Ni Luh Suriani. "Effect of Storage Temperature and Time on Vitamin C Content on White Raw Chili (Capsicum Frustescens". (Pengaruh Suhu Dan Lama Penyimpanan Terhadap Kandungan Vitamin C Pada Cabai Rawit Putih (Capsicum Frustescens))., Jurnal Biologi. 2009. XIII (2) : 36 - 40. 